\title{
Changes to the quantity and processing of starchy foods in a Western diet can increase polysaccharides escaping digestion and improve in vitro fermentation variables
}

\author{
Anne M. Birkett ${ }^{1}$, John C. Mathers ${ }^{2}$, Gwyn P. Jones ${ }^{1}$, Karen Z. Walker ${ }^{3}$, Melinda J. Roth ${ }^{1}$ \\ and Jane G. Muir ${ }^{3 *}$ \\ ${ }^{1}$ School of Nutrition and Public Health, Deakin University, Geelong, Victoria, Australia, 3217 \\ ${ }^{2}$ Human Nutrition Research Centre, Department of Biological and Nutritional Sciences, \\ University of Newcastle Upon Tyne NE1 7RU, UK \\ ${ }^{3}$ Centre for Population Health and Nutrition, Monash University, Clayton, Victoria, Australia, 3168
}

(Received 2 February 1999 - Revised 25 October 1999 - Accepted 25 November 1999)

\begin{abstract}
This study investigated how readily achievable changes to the quantity and processing of starchy foods in a typical Western diet: (1) were reflected in levels of resistant starch (RS) and NSP excreted from the small intestine; and (2) more favourable profiles of butyrate, $\mathrm{NH}_{3}$ and phenol production. Two diets, a low-starch diet (LSD) and a high-starch, low-fat diet (HSLFD) were compared. The LSD with $20 \%$ total energy (\%) from starch was based on a 'typical' Australian diet, while the HSLFD (40\% E as starch) was the same Australian diet modified by an increased content of legumes, starchy foods and coarsely-ground cereals and by a reduced fat content. Four subjects with iliostomies consumed each diet for $2 \mathrm{~d}$, with ileal effluent collection on the second day. On the HSLFD compared with the LSD, RS in ileal effluent increased from from 0.49 to $1.7 \mathrm{~g} / \mathrm{MJ}$ per d $(P<0.005)$ while ileal NSP excretion increased from 2.0 to $3.3 \mathrm{~g} / \mathrm{MJ}$ per d $(P<0 \cdot 05)$. Ileal effluents obtained after each diet were incubated for $24 \mathrm{~h}$ in vitro with a human faecal innoculum. After fermentation, ileal effluent from the HSLFD produced more butyrate relative to other short-chain fatty acids $(17.5 v .15 .8$ molar $\%, P<0.005)$ and less phenol $(2.3 v$. $5.7 \mathrm{mg} / \mathrm{l}, P<0.05)$ and $\mathrm{NH}_{3}(20.3 v .23 \cdot 1 \mathrm{mmol} / \mathrm{l}, P<0.005)$ than the LSD diet. The HSLFD also generated a lower $\mathrm{pH}(6 \cdot 15$ v. $6 \cdot 27, P<0 \cdot 05)$. On a wt/wt basis, RS was $2 \cdot 3$-fold higher in the HSLFD effluent while NSP did not increase, suggesting that the change in RS largely contributed to the fermentation effects. Changes in in vitro variables when the HSLFD ileal effluent was ground before fermentation indicated the importance of physical structure in determining ileal excretion of RS. We conclude that: (1) readily achievable modifications to the amount and processing of starchy foods in an Australian diet would produce potential benefits for in vitro fermentation variables; and (2) the physical structure of grains and cereals is important in determining access by colonic bacteria to a carbohydrate substrate.
\end{abstract}

Ileostomy: Undigested polysaccharides: In vitro fermentation

Increased consumption of indigestible polysaccharides, rich in resistant starch (RS) and NSP may favourably influence human colonic events (van Munster et al. 1994; Phillips et al. 1995; Stephen et al. 1995; Birkett et al. 1996; Cummings et al. 1996). In the colon, indigestible polysaccharides enhance faecal bulking (Jenkins et al. 1987; Lampe et al. 1993; Phillips et al. 1995; Stephen et al. 1995; Cummings et al. 1996), thereby diluting potential carcinogens and cytotoxic compounds such as $\mathrm{NH}_{3}$ and phenols (Mortensen, 1992; Birkett et al. 1996). Further, RS and
NSP are fermented and metabolised by the colonic bacteria, stimulating increased bacterial growth (Scheppach et al. $1988 a$ ), which in turn increases short-chain fatty acid (SCFA) production, leading to a lower lumen $\mathrm{pH}$ (Phillips et al. 1995). These effects are all potentially protective against colonic diseases such as colon cancer (Boutwell \& Bosch, 1959; Candido et al. 1978; Visek, 1978; Roediger, 1982; Walker et al. 1986; Cummings et al. 1992).

Although nutritionists have long recommended an increased consumption of indigestible polysaccharides in

\footnotetext{
Abbreviations: \%E, percentage of energy; HSLFD, high-starch, low-fat diet; LSD, low-starch diet; RS, resistant starch; SCFA, short-chain fatty acids. * Corresponding author: Dr Jane Muir, fax +61 39550 5509, email jane.muir@med.monash.edu.au
} 
the Western diet, for many people intake remains low. An intake of around $18 \mathrm{~g} \mathrm{NSP} / \mathrm{d}$ and $20 \mathrm{~g}$ RS/d appears necessary for beneficial effects to the bowel (Cummings \& Englyst, 1995; Baghurst et al. 1996). We have estimated the intake of NSP by Australians to be $14 \mathrm{~g} / \mathrm{d}$ (Birkett et al. 1997) and RS intake has been estimated at $5 \mathrm{~g} / \mathrm{d}$ (Baghurst et al. 1996; Birkett et al. 1997). The content of RS and NSP in the Australian diet could be increased by two relatively simple dietary changes. First, by the replacement of some dietary fat with more starch-containing foods to increase consumption of NSP and RS. Second, by the inclusion of some modest changes to the physical structure of starchy foods (e.g. coarse grinding of cereals) to ensure that a greater proportion of RS reaches the colon (Livesey et al. 1995; Muir et al. 1995). In this paper, we investigate, in an ileostomy model, the impact of these two moderate dietary changes on the delivery of indigestible polysaccharides to the colon. A third strategy, whereby RS content of foods can be increased, i.e. by supplementing breads and cereals with high amylose starch (van Munster et al. 1994; Muir et al. 1995; Noakes et al. 1996) has not been used in this present study.

Use of a human ileostomy model enables non-invasive, quantitative collection of the material that would normally be available as substrate for fermentation in the colon of healthy intact subjects. It must be noted, however, that the ileostomate model does not exactly reflect the situation in intact human subjects. Studies on ileostomy subjects consuming a wheat bread-based or an oat-bran-based diet have indicated a contribution from both endogenous and microbial sources to dietary fibre residues in ileal excreta (Aman et al. 1995; Sundberg et al. 1996). Nevertheless, the availability of ileal effluent has allowed investigation of the effects of diet on colonic metabolism, via fermentation of effluent in vitro with an inoculum of human faeces. By this means the direct observation of simulated colonic fermentation is possible. The technique is relatively simple and results correlate well with in vivo events (Rumney \& Rowland, 1992; Barry et al. 1995). When ileal effluent is unavailable, fermentation of dietary fibre isolates from foods, but not the fermentation of complete foods, provide the closest estimates of colonic SCFA production (McBurney et al. 1988).

In this present paper we compare a simulated Australian diet, based on the average intake reported by food frequency questionnaire by nearly 3000 adults (Baghurst et al. 1993; Walker et al. 1997) with a similar diet enriched with starchy and unprocessed foods and lower in fat. Our study quantifies how these modest changes: (1) may increase RS and NSP content in ileal excreta and (2) provide increased substrates for bacterial fermentation, potentially increasing levels of beneficial SCFA and decreasing levels of harmful $\mathrm{NH}_{3}$ and phenols.

\section{Materials and methods}

Subjects and study design

The four subjects who participated in this study (one male, three females) were recruited through the Ostomy Association of Geelong, Victoria, Australia. Each had undergone a total colectomy for ulcerative colitis (average duration since surgery 14 years, range $3-34$ years), but no more than $10 \mathrm{~cm}$ of the terminal ileum was removed. All subjects were in good health, and none had taken antibiotics or medication, that might alter small intestinal function, at least 1 month prior to the study. The average age was 58 years (range $49-$ 69 years) and average BMI was $22 \mathrm{~kg} / \mathrm{m}^{2}$ (range $18-24 \mathrm{~kg}$ / $\mathrm{m}^{2}$ ). No intolerances were reported for foods consumed in this study. Ethical approval for the study was given by the Deakin University Human Ethics Committee (no. EC 16/94).

The study followed a standard protocol for starch digestion studies in subjects with ileostomies (Asp, 1991). There were two test dietary periods, each of two days duration, separated by a week or more, when subjects consumed their habitual diet. All subjects participated in the study while in their own homes, and were visited daily for $3 \mathrm{~d}$ during each test period.

Subjects received the same diet (Table 1) for each day of a test period. Day 1 was used as a 'run-in' to acquaint subjects with the diet and protocol, while on day 2 effluent was collected. All food provided was consumed between 07.00 and 18.00 hours. On day 2 , subjects were asked to empty or change their ileostomy bag at 07.00 hours, and then to empty the bag and immediately freeze all its contents in plastic containers every $2 \mathrm{~h}$ until 23.00 hours. On day 3 a final collection was made at 07.00 hours. At 18.00 hours on day 2, after the evening meal, subjects consumed a gelatine capsule containing polyvinyl chloride markers (Terumo (Aust.) Pty Ltd, Melbourne, Victoria, Australia). The presence of these markers in ileal effluent was used to indicate the completeness of the collection of undigested residue from the final evening meal.

\section{Diets}

'Typical' Australian low-starch diet. The 'typical' Australian low-starch diet (LSD) was based on self-reported data of usual dietary intake of nearly 3000 subjects over the age of 18 years surveyed in Victoria, Australia in 1990 (Baghurst et al. 1993). Data from this 1990 Victorian Nutrition Survey included the average amount of food eaten by each subject for over 100 common food items (H. Stafford, unpublished results). This list was reduced to seventy-four individual foods that were each consumed by over $50 \%$ of the population surveyed and eaten in quantities greater than $5 \mathrm{~g} / \mathrm{d}$. A 'typical' Australian diet was then constructed from these foods with intake of each food item in this diet adjusted to within $5 \%$ of the average amount of that consumed by subjects in the 1990 Nutrition Survey. This adjustment of food quantities also ensured that the macronutrient content of the diet matched the average macronutrient intake reported in the survey (Table 1). All foods for the LSD were purchased at a major supermarket in Geelong, Victoria and were prepared in a form that subjects could eat without further processing.

High-starch, low-fat diet. The high-starch, low-fat diet (HSLFD) was based on the LSD but was modified to include a reduced fat intake and a larger intake of starchy foods, some of which were provided in a less processed form than in the LSD. Some meat was replaced by red kidney beans. Wholegrain muesli and wholegrain bread replaced a more refined wheat-based breakfast biscuit (Weetbix ${ }^{\circledR}$ ) and 
Table 1. Formulation of the experimental diets and suggested meal plan

\begin{tabular}{|c|c|c|}
\hline \multirow[b]{2}{*}{ Meal } & \multicolumn{2}{|c|}{ Foods included in experimental diets $(\mathrm{g})^{*}$} \\
\hline & Low-starch diet & High-starch, low-fat diet \\
\hline Breakfast (08.00 hours) & $\begin{array}{l}\text { Wholewheat breakfast biscuit }(30 \mathrm{~g}) \dagger \text {, milk }(200 \mathrm{~g}) \\
\text { Wholegrain bread (toasted) }(60 \mathrm{~g}) \S \\
\text { Margarine }(10 \mathrm{~g}) \text {, jam }(26 \mathrm{~g}) \\
\text { Orange juice }(131 \mathrm{~g})\end{array}$ & $\begin{array}{l}\text { Muesli }(90 \mathrm{~g}) \neq \text {, skimmed milk }(251 \mathrm{~g}) \\
\text { Toast made from wholegrain bread }(60 \mathrm{~g}) \S \\
\text { Margarine }(14 \mathrm{~g}) \\
\text { Orange juice }(262 \mathrm{~g})\end{array}$ \\
\hline Morning tea & $\begin{array}{l}\text { Sweet biscuit }(9 \mathrm{~g}) \\
\text { Chocolate }(15 \mathrm{~g}) \\
\text { Water }(250 \mathrm{~g})\end{array}$ & $\begin{array}{l}\text { Fruit salad }(134 \mathrm{~g}) \text {, Rice }(100 \mathrm{~g}) \\
\text { Yoghurt }(100 \mathrm{~g}) \\
\text { Water }(250 \mathrm{~g})\end{array}$ \\
\hline Lunch & $\begin{array}{l}\text { Sandwich: } \\
\text { White bread }(84 \mathrm{~g}) \\
\text { Margarine }(10 \mathrm{~g}) \\
\text { Lettuce }(50 \mathrm{~g}) \\
\text { Cucumber }(45 \mathrm{~g}) \\
\text { Tomato }(55 \mathrm{~g}) \\
\text { Cheese }(13 \mathrm{~g}) \\
\text { Chicken }(49 \mathrm{~g}) \\
\text { Lemonade }(391 \mathrm{~g})\end{array}$ & $\begin{array}{l}\text { Toast made from wholegrain bread }(120 \mathrm{~g}) \S \\
\text { Margarine }(27 \mathrm{~g}) \\
\text { Tomato }(40 \mathrm{~g}) \\
\text { Water }(250 \mathrm{~g})\end{array}$ \\
\hline Afternoon tea & $\begin{array}{l}\text { White bread roll }(54 \mathrm{~g}) \\
\text { Tomato }(55 \mathrm{~g}) \\
\text { Margarine }(9 \mathrm{~g}) \\
\text { Milk }(239 \mathrm{~g}) \\
\text { Water }(250 \mathrm{~g})\end{array}$ & $\begin{array}{l}\text { Mixed salad: } \\
\text { Rice }(100 \mathrm{~g}) \\
\text { Tomato }(37 \mathrm{~g}) \\
\text { Lettuce }(50 \mathrm{~g}) \\
\text { Kidney beans }(40 \mathrm{~g}) \\
\text { Cucumber }(45 \mathrm{~g}) \\
\text { Olive oil }(10 \mathrm{~g}) \\
\text { Water }(250 \mathrm{~g})\end{array}$ \\
\hline Dinner (18.00 hours) & $\begin{array}{l}\text { Rump steak }(84 \mathrm{~g}) \text {, sausage }(75 \mathrm{~g}) \\
\text { Potato }(69 \mathrm{~g}) \\
\text { Peas }(24 \mathrm{~g}) \text {, beans }(19 \mathrm{~g}) \text {, carrot }(113 \mathrm{~g}) \\
\text { Fruit salad }(206 \mathrm{~g}) \| \text {, ice cream }(48 \mathrm{~g}) \\
\text { Beer }(283 \mathrm{~g}) \\
\text { Water }(250 \mathrm{~g})\end{array}$ & $\begin{array}{l}\text { Rump steak }(30 \mathrm{~g}) \\
\text { Rice }(237 \mathrm{~g}) \text {, potato }(60 \mathrm{~g}) \\
\text { Beans }(63 \mathrm{~g}), \text { peas }(16 \mathrm{~g}) \text {, carrot }(150 \mathrm{~g}) \\
\text { Fruit salad }(100 \mathrm{~g}) \| \text {, yoghurt }(100 \mathrm{~g}) \\
\text { Beer }(283 \mathrm{~g}) \\
\text { Water }(250 \mathrm{~g})\end{array}$ \\
\hline
\end{tabular}

* Additional water, black tea and black coffee were available ad libitum.

†The wholewheat breakfast biscuit was Weetbix ${ }^{\circledR}$.

$\ddagger$ The muesli was a dry mixture of $(\mathrm{g})$ : oatmeal 10 , barley flakes 20 , wheaflakes 20 , sesame seeds 5 , cornflakes 10 , sultanas 10 , sunflower seeds 5 , millet 10 .

$\S$ The wholegrain bread contained parboiled whole wheatgrains and cracked wheat.

॥The fruit salad was $(\mathrm{g})$ : orange 23 , apple $29 \cdot 5$, banana 30.5 , strawberry $6 \cdot 5$, watermelon 10.5 .

wholemeal bread. Muesli and wholegrain bread were prepared especially for the study. Muesli consisted of $(\mathrm{g})$ : oatmeal 10 , barley flakes 20 , wheat flakes 20 , sesame seeds 5 , cornflakes 10 , sultanas 10 , sunflower seeds 5 , millet 10 . This dry mixture of grains was eaten with milk as a breakfast meal. Each $1 \mathrm{~kg}$ loaf of wholegrain bread was made from $(\mathrm{g})$ : wholewheat grains (par-boiled 1 minute) 150, cracked wheat (particle size 1-3 mm) 300, cracked wheat (particle size $<1 \mathrm{~mm}$ ) 274, gluten 50, salt 15 , yeast $7 \cdot 5$, water 395 . Basmati rice, which has a high amylose content and a low glycaemic index (Foster-Powell \& Brand-Miller, 1995), replaced long-grain white rice. Both diets included a fruit salad made up of $(\mathrm{g})$ : orange 23 , peeled apple 29.5 , banana $30 \cdot 5$, strawberries $6 \cdot 5$, peeled and seeded watermelon $10 \cdot 5$. All food preparation employed simple methods commonly used in Australian homes.

The macronutrient contents of the LSD and HSLFD were analysed using SODA 5.0 (Computer Models, Cottesloe, Australia) based on a food composition database of Australian foods (National Food Authority, 1991). Values for NSP, however, were calculated manually using data from British food composition tables (Holland et al. 1988, 1991,
1992). The amount of food supplied to each subject was determined from their habitual energy intake, calculated from a $7 \mathrm{~d}$ weighed food record, analysed as described earlier with SODA 5.0 (Computer Models). Subjects were instructed to consume all food supplied. Any uneaten food portions were returned for weighing. Additional bread was supplied in case the subjects became hungry, but this was never eaten. Black tea and coffee and water were provided ad libitum.

\section{Sample analysis}

Ileal effluent analysis. Frozen effluent samples were weighed and thawed rapidly $\left(15 \mathrm{~min}\right.$ in a $30^{\circ} \mathrm{C}$ water-bath). Effluents collected for each $2 \mathrm{~h}$ time point were then pooled for each diet for each of the four subjects and thoroughly stirred to achieve homogeneity. The wet effluent was subsampled immediately after mixing for analysis of $\mathrm{pH}$, SCFA, phenols (phenol and $\rho$-cresol), soluble $\mathrm{N}$, and particle size distribution. $\mathrm{pH}$ was immediately measured by a $\mathrm{pH}$ meter fitted with a protein-resistant glass electrode (AEP 344, Activon Scientific Products, Carlton, Australia). SCFA 
were isolated as described by Phillips et al. (1995) at Royal Melbourne Hospital, Victoria, Australia. They were subsequently separated on a $25 \mathrm{~m} \times 0.5 \mathrm{~mm}$ BP2 1 silica column (SGE Scientific Pty Ltd, Ringwood, Australia) at $100^{\circ} \mathrm{C}$ by GLC (Perkin Elmer, Norwalk, CT, USA) with flame ionisation detection, and quantitated using methylvaleric acid as an internal standard. Phenols were deconjugated by boiling in $\mathrm{HCl}$ and separated by reverse phase HPLC using a $250 \mathrm{~mm} \times 4.6 \mathrm{~mm}$ Econosil RP-18 $5 \mu \mathrm{m}$ column (Alltech, Deerfield, IL, USA), attached to a Waters 501 pump (Milford, MA, USA). The mobile phase was methanol-phosphate buffer $(0.02 \mathrm{M}, \mathrm{pH} 4 ;)(48: 52, \mathrm{v} / \mathrm{v})$ infused at a rate of $0.7 \mathrm{ml} / \mathrm{min}$. Phenols were measured with a u.v. detector at $270 \mathrm{~nm}$ (Barspec, Hart Analytical, Collingwood, Australia) (Birkett et al. 1995). Total soluble $\mathrm{N}$ was determined as the quantity of $\mathrm{N}$ soluble in phosphate buffer $(0 \cdot 1 \mathrm{~mol} / \mathrm{l}, \mathrm{pH} 7)$, after centrifuging at $1500 \mathrm{~g}$. $\mathrm{N}$ was determined by a semi-automated Kjeldahl apparatus (Gerhardt, Bonn, Germany). It should be noted that this assay measures total nitrogenous compounds only, and is unable to distinguish the contribution from proteins, polypeptides, peptides, amino acids, urea or $\mathrm{NH}_{3}$ which have to be measured separately. Nevertheless, protein and products of protein breakdown are likely to represent the major contributors and so the term protein has been used in the results and discussion sections of this paper.

Large particles present in the ileostomy effluents (i.e. with a diameter $>2.8 \mathrm{~mm}$ or $>1 \mathrm{~mm}$ ) were estimated by washing an aliquot of effluent sequentially through two sieves $(2.8 \mathrm{~mm}$ : CE Propert Pty Ltd, China; $1 \mathrm{~mm}$ : Chef, Hong Kong) using distilled water. The particles were then collected, dried and weighed.

Aliquots of pooled ileal effluent were freeze-dried, and used for all subsequent determinations. Energy content was measured against a benzoic acid standard by bomb calorimetry (Gallenkamp, Loughborough, Leics, UK). N was determined by a semi-automated Kjeldahl apparatus as described earlier. Starch was determined with a commercial kit which employed dimethylsulfoxide dissolution and enzymatic hydrolysis before spectrophotometric determination of the released glucose (Total Starch Kit AA/AMG, Megazyme Australia, Sydney, Australia). NSP (total and insoluble) was measured by the colorimetric method of Englyst \& Cummings (1988). Total dietary fibre was analysed by the enzymatic-gravimetric method of Prosky et al. (1985) and total lipid content was determined gravimetrically after chloroform-methanol extraction (Folch et al. 1957). Oligosaccharides (raffinose and stachyose) were also analysed by GC using the method described by Karoutis et al. (1992). Raffinose and stachyose were measured only and not inulin, as these are the most important classes of oligosaccharides in legumes. Inulin oligosaccharides were not measured because these occur in smaller concentrations in foods which were not consumed in large quantities during the course of this study (e.g. onion, artichokes).

\section{In vitro fermentation}

The inoculum for all in vitro fermentation studies described here was provided from pooled fresh faecal samples obtained from two male subjects (age 25 and 42 years) who had not taken antibiotics or laxatives within the preceding month.

In vitro fermentation was carried out as described by Edwards et al. (1996) in the laboratories of J. Mathers, University of Newcastle Upon Tyne, UK. The substrate was provided as $100 \mathrm{mg}$ portions of pooled, dried and ground ileal effluent in $60 \mathrm{ml}$ screw-top tubes to which $10 \mathrm{ml}$ of a $16 \%$ faecal slurry (diluted with phosphate buffer, $0 \cdot 1 \mathrm{~mol} / \mathrm{l}$, $\mathrm{pH}$ 7) was added as an inoculum. These tubes were then gassed with $\mathrm{N}_{2}$, sealed and incubated in an orbital shaker (Gallenkamp) at $37^{\circ} \mathrm{C}$ for $0,3,6,9,24,36$, or $48 \mathrm{~h}$. At each time point, when tubes were harvested, the tube contents were mixed by vortexing, $\mathrm{pH}$ was recorded (PHM-110070N, Russel pH Limited, Witchford, Cambs., UK), aliquots were removed for SCFA, $\mathrm{NH}_{3}$ and glucose analysis, and fermentation was then stopped with the addition of $40 \mathrm{ml}$ ethanol.

Measurement of SCFA was also undertaken in the laboratories of J. Mathers, as earlier. In this assay, aliquots of incubation fluid were de-proteinised (Mathers et al. 1990) before SCFA determination by GLC (Pye Unicam PU4550, Philips, Cambridge, Cambs., UK) using a $1.5 \mathrm{~m} \times 2 \mathrm{~mm}$ glass column with GP $10 \%$ SP-1200 packing on Chromosorb WAW support (Supelco, Bellefonte, PA, USA). $\mathrm{NH}_{3}$ was determined by automated analysis via the Berthelot reaction (Cobas Mira, Roche, Basel, Switzerland). Free glucose was determined with an enzymatic assay (GLUC GDH, Roche, Basel, Switzerland) using an automated analyser (Cobas Mira, Roche, Basel, Switzerland). The ethanolic incubation mixture was centrifuged at $1500 \mathrm{~g}$ (Mistral 3000i, SH Scientific, UK) and soluble $\mathrm{N}$ in the supernatant was measured by micro-Kjeldahl digestion (Gerhardt, Bonn, Germany) and the automated Berthelot reaction. Starch in the incubation mixture pellet was solubilised by dimethylsulfoxide and hydrolysed (Englyst \& Cummings, 1988) before the released glucose was determined enzymatically (GLUC GDH, Roche, Basel, Switzerland) on an automated analyser, as earlier. NSP levels were determined by the colorimetric assay of Englyst \& Cummings (1988).

Duplicate fermentation tubes were prepared for the 0,24 and $48 \mathrm{~h}$ time points. These were boiled to stop the bacterial fermentation before phenols (phenol and $\rho$-cresol) were measured by HPLC as earlier (Birkett et al. 1995).

In the standard in vitro fermentation method described by Edwards et al. (1996) the substrate is ground so that a representative homogeneous sample can be fermented. This process, however, disrupts type 1 RS (Englyst et al. 1992). To investigate the effect of particle size or structure on fermentation, incubations were carried out with $100 \mathrm{mg}$ dried ileal effluent from the HSLFD that had not been ground. Results were then compared with those from similar incubations with a ground substrate.

\section{Statistical analysis}

Results are presented as the mean and standard error of the mean. Data have been compared by one-tailed paired Student $t$ test, with $n 4$ and degrees of freedom 3. Significance was taken where $P<0.05$. Statistical analyses were performed using the Minitab Release 8.21 software package (Minitab Inc, State College, PA, USA). 


\section{Results}

\section{Diets and ileal effluent output}

The menus for the LSD and HSLFD are presented in Table 1. Food intake was divided into three main meals and three smaller meals per day. Both diets were well

Table 2. Macronutrient composition of the experimental diets expressed as both nutrient intake $(\mathrm{g} / 10 \mathrm{MJ})$ and percentage of energy (\%E)

\begin{tabular}{lccccr}
\hline & \multicolumn{2}{c}{ Low-starch diet } & & \multicolumn{2}{c}{$\begin{array}{c}\text { High-starch, } \\
\text { low-fat diet }\end{array}$} \\
\cline { 2 - 3 } \cline { 5 - 6 } Macronutrient & g/10 MJ & \%E & & g/10 MJ & $\% \mathrm{E}$ \\
\hline Carbohydrate & & & & & \\
$\quad$ total & 273 & 44 & & 351 & 56 \\
$\quad$ starch & 123 & 20 & & 252 & 40 \\
Protein & 104 & 18 & & 87 & 15 \\
Fat & 92 & 34 & & 62 & 23 \\
Alcohol & 11 & 3 & & 11 & 3 \\
Dietary fibre & 26 & & & 45 & \\
NSP & & & & 30 & \\
$\quad$ total & 17 & & & 18 & \\
$\quad$ insoluble & 9 & & & 12 & \\
$\quad$ soluble & 8 & & & \\
\hline
\end{tabular}

Table 3. Characteristics of ileal effluent collected during the lowstarch diet (LSD) and the high-starch, low-fat diet (HSLFD) $†$

(Mean values with standard errors for $n 4$ per diet)

\begin{tabular}{lcccccc}
\hline & \multicolumn{2}{c}{ LSD } & & \multicolumn{2}{c}{ HSLFD } \\
\cline { 2 - 3 } \cline { 6 - 7 } & Mean & SE & & Mean & SE \\
\hline Wet wt $(\mathrm{g})$ & 673 & 41 & & $819^{*}$ & 17 \\
Dry wt $(\mathrm{g})$ & 56 & 9 & & $83^{\star *}$ & 7 \\
Wet wt with particle size $>2.8 \mathrm{~mm}(\%)$ & 1.5 & 0.5 & & $4.2^{\star * *}$ & 0.9
\end{tabular}

Mean values were significantly different from those of the low-starch-diet group (Student's $t$ test): ${ }^{*} P<0.05,{ }^{* *} P<0.01,{ }^{* *} P<0.005$

† For details of diets and procedures see Tables 1 and 2 and pp. 64-66. received by the subjects, who recorded their responses in a questionnaire (data not shown). The LSD was recognised as being similar to the subjects' habitual diet. The macronutrient composition of the two diets is presented in Table 2. The LSD contained $44 \%$ total energy $(\% \mathrm{E})$ as carbohydrate with $20 \% \mathrm{E}$ present as starch. In the HSLFD, carbohydrate intake was increased to $56 \% \mathrm{E}$ with $40 \% \mathrm{E}$ present as starch. Dietary fibre intake on the HSLFD was increased from 26 to $45 \mathrm{~g} / \mathrm{d}$. Total fat content was $34 \% \mathrm{E}$ on the LSD, but only $23 \% \mathrm{E}$ on the HSLFD.

Ileostomy output over $24 \mathrm{~h}$ differed significantly between diets (Table 3 ) both in terms of wet weight evacuated (LSD 673 (SE 41) v. HSLFD 819 (SE 17) g, $P<0.05$ ) and dry weight (LSD 56 (SE 9) $v$. HSLFD 83 (SE 7) g, $P<0.01$ ). Effluent from both diets contained visible fragments of food. Peas, fruit seeds, vegetable seeds and vegetable skins could be identified. In addition, the effluent after the HSLFD contained whole rice and cereal grains, more varieties of seeds and fragments of kidney bean. Further, a significantly higher proportion of large particles (diameter $>2.8 \mathrm{~mm}$ ) calculated as a percentage of total wet weight were excreted on the HSLFD (LSD 1.5 (SE 0.5) $v$. HSLFD $4 \cdot 2$ (SE 0.9) \%) (Table 3).

To confirm that minimal fermentation had occurred during the collection, storage and processing of ileal effluents, their pH, SCFA and phenols were measured. Effluents collected after either diet did not differ in pH (LSD 7.58 (SE 0.08) v. HSLFD 7.28 (SE 0.10)). Total phenol concentration in effluent from the LSD was low $(0.5 \mu \mathrm{g} / \mathrm{g}(\mathrm{SE} 0 \cdot 1), n 4)$ as was the concentration of SCFA (21.5 (SE 7.1) $\mu \mathrm{mol} / \mathrm{g}, n 2)$.

Ileal effluent composition was significantly influenced by diet composition (Table 4). On the HSLFD, subjects excreted a larger amount of energy $(P<0 \cdot 01)$ due to the presence of increased amounts of undigested starch (RS) $(P<0.005)$, NSP $(P<0.01)$ and protein $(P<0.05)$. On the HSLFD, RS excretion was increased almost 4 -fold from $3.5 \mathrm{~g} / \mathrm{d}(4.9 \mathrm{~g} /$ $10 \mathrm{MJ}$ per $\mathrm{d})$ to $11.8 \mathrm{~g} / \mathrm{d}(17.0 \mathrm{~g} / 10 \mathrm{MJ}$ per $\mathrm{d})$. The content of

Table 4. Comparison between nutrient intake, calculated from food composition tables, and ileal excretion ( $\mathrm{g} / \mathrm{d}$ ) of macronutrients $† \ddagger$ (Mean values with standard errors for $n 4$ per diet)

\begin{tabular}{|c|c|c|c|c|c|c|c|c|c|c|c|c|}
\hline \multirow[b]{3}{*}{ Nutrient } & \multicolumn{6}{|c|}{ Low-starch diet } & \multicolumn{6}{|c|}{ High-starch, low-fat diet } \\
\hline & \multicolumn{2}{|c|}{ Intake } & \multicolumn{2}{|c|}{ Excretion } & \multicolumn{2}{|c|}{$\%$ Excreted } & \multicolumn{2}{|c|}{ Intake } & \multicolumn{2}{|c|}{ Excretion } & \multicolumn{2}{|c|}{$\%$ Excreted } \\
\hline & Mean & SE & Mean & SE & Mean & SE & Mean & SE & Mean & SE & Mean & SE \\
\hline Energy (kJ) & 7204 & 693 & 828 & 177 & 11.4 & $1 \cdot 7$ & 6923 & 881 & $1310^{* \star *}$ & 152 & $19 \cdot 1^{* * *}$ & 1.1 \\
\hline Total starch (g) & 88 & 8 & 3.5 & 0.8 & $3 \cdot 8$ & 0.7 & $176^{\star *}$ & 24 & $11 \cdot 8^{* * *}$ & $1 \cdot 2$ & $6 \cdot 9^{*}$ & 0.7 \\
\hline Protein $(\mathrm{g})$ & 76 & 7 & 11.7 & 2.5 & $15 \cdot 6$ & $2 \cdot 8$ & $60^{* * *}$ & 8 & $15 \cdot 6^{*}$ & $2 \cdot 4$ & $26 \cdot 2^{* * *}$ & 2.7 \\
\hline Fat $(\mathrm{g})$ & 65 & 7 & $3 \cdot 8$ & $2 \cdot 2$ & 5.4 & $2 \cdot 6$ & $42^{* * *}$ & 5 & 4.9 & $1 \cdot 7$ & $11 \cdot 3^{* * *}$ & 2.7 \\
\hline Dietary fibre (g) & 19 & 2 & $19 \cdot 3$ & $2 \cdot 4$ & $99 \cdot 7$ & 4.9 & $31^{* *}$ & 4 & $29 \cdot 9^{\star \star \star}$ & $2 \cdot 6$ & $100 \cdot 5$ & $7 \cdot 1$ \\
\hline \multicolumn{13}{|l|}{ NSP } \\
\hline total $(\mathrm{g})$ & 13 & 1 & $14 \cdot 6$ & 1.4 & 117.5 & $5 \cdot 5$ & $21^{* *}$ & 3 & $22 \cdot 5^{\star *}$ & $2 \cdot 0$ & $112 \cdot 8$ & 8.9 \\
\hline soluble (g) & 6 & 1 & $7 \cdot 5$ & 0.9 & $124 \cdot 7$ & 8.9 & $8^{*}$ & 1 & $10 \cdot 8^{*}$ & $1 \cdot 3$ & $140 \cdot 6$ & $10 \cdot 9$ \\
\hline insoluble (g) & 7 & 1 & $7 \cdot 1$ & 0.5 & $102 \cdot 2$ & $2 \cdot 3$ & $13^{* *}$ & 2 & $11 \cdot 7^{\star \star *}$ & 0.8 & $97 \cdot 2$ & $8 \cdot 3$ \\
\hline $\mathrm{RS}+\mathrm{NSP}(\mathrm{g})$ & & & $18 \cdot 1$ & $2 \cdot 0$ & & & & & $34 \cdot 3^{\star \star *}$ & $2 \cdot 6$ & & \\
\hline \multicolumn{13}{|l|}{ Oligosaccharides } \\
\hline Raffinose (g) & \multirow{2}{*}{\multicolumn{2}{|c|}{$\begin{array}{l}\text { NA } \\
\text { NA }\end{array}$}} & 0.25 & $0 \cdot 13$ & \multirow{2}{*}{\multicolumn{2}{|c|}{-}} & \multirow{2}{*}{\multicolumn{2}{|c|}{$\begin{array}{l}\text { NA } \\
\text { NA }\end{array}$}} & 0.86 & 0.32 & \multicolumn{2}{|l|}{-} \\
\hline Stachyose (g) & & & \multicolumn{2}{|c|}{ ND } & & & & & $0 \cdot 18$ & 0.1 & - & \\
\hline
\end{tabular}

RS, resistant starch; NSP, non-starch polysaccharides; NA, not analysed; ND, not detected.

Mean values were significantly different from those of the low-starch-diet group (Student's $t$ test): ${ }^{\star} P<0.05,{ }^{* *} P<0.01,{ }^{\star \star \star} P<0.005$.

† Macronutrient intake was calculated using a food composition database SODA 5.0 (Computer Models, Cotlesloe, Australia. NSP was calculated using British food composition tables (Holland et al 1988, 1991, 1992).

¥For details of diets and procedures see Tables 1 and 2 and pp. 64-66. 
total undigested polysaccharides (RS + NSP) in ileal effluent after the HSLFD was 34.3 (SE 2.6) g. This value was nearly double the amount of 18.1 (SE 2.0) $\mathrm{g}$ found after the LSD. There was a significant increase in the proportion of ingested energy, protein, fat (all $P<0.005)$ and starch $(P<0.05)$ excreted from the HSLFD. The total dietary fibre output in effluent was also examined as a proportion of dietary input (Table 4). On the LSD, ileal excretion of total dietary fibre was $99.7 \%$ of intake, while on the HSLFD ileal excretion was $100.5 \%$ of intake. There was also a significant increase $(P<0.01)$ in the excretion of the oligosaccharides raffinose and stachyose during the HSLFD (Table 4). Raffinose was increased over 3.4-fold compared to the LSD, but the oligosaccharide stachyose (an important constituent of legumes) was not detected in the effluent of subjects on the LSD.

\section{In vitro fermentation}

Fig. 1 presents $48 \mathrm{~h}$ data for total SCFA concentration and $\mathrm{pH}$ for both diets, and compares this data with blank tubes that contained no effluent. This figure demonstrates the importance of fermentable substrate, since SCFA concentration was considerably higher and the $\mathrm{pH}$ considerably lower when effluent was present in the in vitro fermentation tubes. The majority of SCFA were produced within the first $3 \mathrm{~h}$ period (53\% LSD, $49 \%$ HSLFD), with $89 \%$ and $86 \%$ of the total $48 \mathrm{~h}$ production occurring within $24 \mathrm{~h}$ (LSD and HSLFD respectively). Similarly the majority of the change in $\mathrm{pH}$ occurred within the first $3 \mathrm{~h}$ period $73 \% \mathrm{LSD}, 75 \%$ HSLFD) with $93 \%$ and $89 \%$ of the overall $48 \mathrm{~h}$ change occurring within $24 \mathrm{~h}$ (LSD and HSLFD respectively).

The concentration of end-products resulting from undigested carbohydrate and protein fermentation in ileal effluents after $24 \mathrm{~h}$ in vitro incubation is presented in Table 5. Although data were collected for $48 \mathrm{~h}$, the $24 \mathrm{~h}$ time point only has been chosen for inclusion, to assist in comparison with other in vitro studies. There was no difference between diets in the concentration of total SCFA. The concentration of butyrate, however, increased with the HSLFD (13.8 (SE 1.0 ) $\mathrm{mmol} / \mathrm{l} v .12 .3(\mathrm{SE} 0.6$ ) $\mathrm{mmol} / \mathrm{l}, P=0.055$ ), and the molar proportion of butyrate was also significantly increased (17.5 (SE 0.5) molar \% v. 15.8 (SE 0.6) molar \%, $P<0.005$ ) at the expense of both acetate and propionate. Fermentation of the HSLFD was also associated with a decrease in protein end-products. Fermentation of HSLFD effluent generated significantly less $\mathrm{NH}_{3}(20 \cdot 3$ (SE 1.7) mmol/l v. 23.1 (SE 1.9) $\mathrm{mmol} / \mathrm{l}, P<0.005$ ); branched SCFA (i.e. isobutyrate + isovalerate) $(3.7$ (SE 0.8) $\mathrm{mmol} / \mathrm{l}$ v. 4.6 (SE 0.8$) \mathrm{mmol} / \mathrm{l}, P<$ 0.05); and phenol (2.3 (SE 0.6) $\mathrm{mg} / \mathrm{l} v .5 .7$ (SE 0.9) $\mathrm{mg} / \mathrm{l}, P<$ $0 \cdot 05)$. These changes are consistent with the observation that although absolute levels of protein excreted in ileal effluent rose on the HSLFD (from 11.7 to $15.6 \mathrm{~g}, P<0.05$ ) (Table 4), the relative proportion of protein in the effluent declined from 34.8 to $28.5 \%$. Changes in fermentation on the HSLFD were accompanied by a reduced $\mathrm{pH}(6 \cdot 15$ (SE 0.07) v. 6.27 (SE 0.11), $P<0.05$ ). There was no significant difference in soluble $\mathrm{N}$ concentration (data not shown).

Data for production of total SCFA and butyrate from the $24 \mathrm{~h}$ fermentation of $100 \mathrm{mg}$ dry effluent together with data
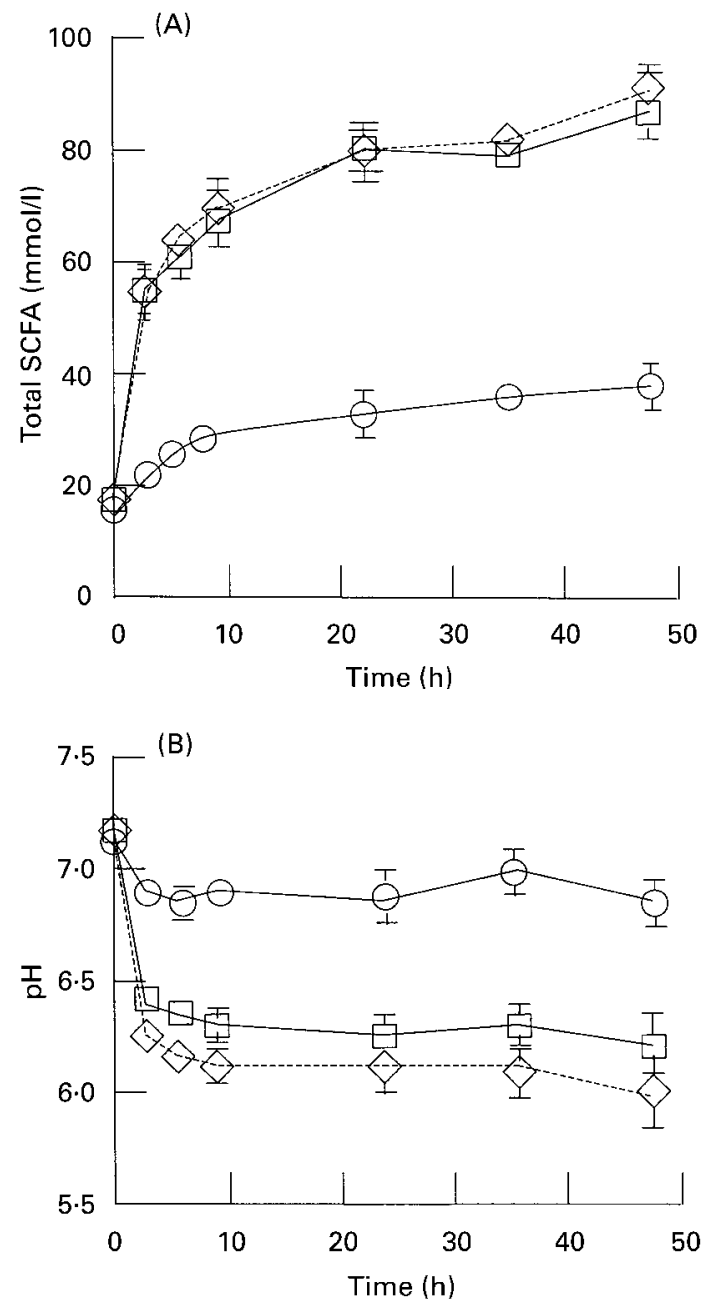

Fig. 1. Accumulation of total short-chain fatty acids (SCFA) (A) and change in $\mathrm{pH}(\mathrm{B})$ during $48 \mathrm{~h}$ in vitro incubation of $100 \mathrm{mg}$ dry effluent. $-\square-$, low-starch diet effluent; - - - $\diamond--$-, high-starch diet effluent; -O-, no effluent (human faecal inoculum only). For details of diets and procedures see Tables 1 and 2 and pp. 64-66. Values are means for four samples with standard errors represented by vertical bars.

on the total amount of effluent excreted per $d$ were used to estimate potential total daily production of SCFA. The HSLFD with increased daily excretion of ileal solids (Table 1), potentially would yield significantly more total SCFA (423 (SE 50) $\mathrm{mmol} / \mathrm{d} v .620$ (SE 25) $\mathrm{mmol} / \mathrm{d}, P<0.005)$ and butyrate (65 (SE 6) mmol/d v. 108 (SE 3) mmol/d, $P<0.005$ ) than the LSD.

\section{Particle size effects}

The in vitro fermentation technique usually employs ground ileal effluent as a substrate (Edwards et al. 1996). Grinding may, however, expose starch and other substrates that would otherwise be physically trapped in the tissues of grains (i.e. type 1 RS) and remain unavailable to the action of bacteria. In this study it was observed that the ileal effluent after the HSLFD was much richer in particulate matter than the ileal effluent after the LSD. To determine the effects of entrapment of carbohydrate within particles of this type, duplicate 
Table 5. Concentration and molar proportion of short-chain fatty acids (SCFA), ammonia, phenols and $\mathrm{pH}$ in the fermentation mixture after $24 \mathrm{~h}$ in vitro incubation of ileal effluent following consumption of a lowstarch diet (LSD) or a high-starch, low-fat diet (HSLFD)†

(Mean values with standard errors for $n 4$ per diet)

\begin{tabular}{|c|c|c|c|c|}
\hline \multirow[b]{3}{*}{ Fermentation end-product } & \multicolumn{4}{|c|}{ Diet } \\
\hline & \multicolumn{2}{|c|}{ LSD } & \multicolumn{2}{|c|}{ HSLFD } \\
\hline & Mean & SE & Mean & SE \\
\hline \multicolumn{5}{|l|}{ SCFA } \\
\hline Total $(\mathrm{mmol} / \mathrm{l})$ & $79 \cdot 1$ & 2.8 & 78.6 & $4 \cdot 8$ \\
\hline Acetate $(\mathrm{mmol} / \mathrm{l})$ & 39.6 & $2 \cdot 0$ & 38.7 & 2.8 \\
\hline Propionate $(\mathrm{mmol} / \mathrm{l})$ & $19 \cdot 3$ & $1 \cdot 2$ & $18 \cdot 8$ & $1 \cdot 0$ \\
\hline Butyrate $(\mathrm{mmol} / \mathrm{l})$ & $12 \cdot 3$ & 0.6 & $13 \cdot 8 \ddagger$ & $1 \cdot 0$ \\
\hline molar \% & $15 \cdot 8$ & 0.6 & $17 \cdot 5^{\star \star \star}$ & 0.5 \\
\hline Branched-chain $\ddagger(\mathrm{mmol} / \mathrm{l})$ & 4.6 & 0.8 & $3 \cdot 7^{\star}$ & 0.8 \\
\hline Ammonia $(\mathrm{mmol} / \mathrm{l})$ & $23 \cdot 1$ & 1.9 & $20 \cdot 3^{* * *}$ & 1.7 \\
\hline Phenol (mg/l) & 5.7 & 0.9 & $2 \cdot 3^{*}$ & 0.6 \\
\hline$\rho$-Cresol $(\mathrm{mg} / \mathrm{l})$ & 4.9 & 0.5 & 5.2 & $1 \cdot 1$ \\
\hline Total phenols (mg/l) & $10 \cdot 6$ & $1 \cdot 2$ & 7.5 & 1.6 \\
\hline $\mathrm{pH}$ & $6 \cdot 27$ & 0.11 & $6 \cdot 15^{*}$ & 0.07 \\
\hline
\end{tabular}

Mean values were significantly different from those of the low-starch-diet group (Student's $t$ test): $\ddagger P<0.06,{ }^{\star} P<0.05,{ }^{* \star \star} P<0.005$.

†For details of diets and procedures see Tables 1 and 2 and pp. 64-66. $\ddagger$ Branched-chain fatty acids: isobutyrate + isovalerate.

ground and unground samples from the HSLFD were fermented and important differences were observed (Table 6). After $6 \mathrm{~h}$ incubation, the unground effluent produced less SCFA (52.8 (SE 2.8) mmol/l v. 63.6 (SE 2.1) mmol/l, unground and ground respectively, $P<0.05)$, with a significantly higher $\mathrm{pH}(6 \cdot 51$ (SE 0.06) v. $6 \cdot 19$ (SE 0.05), $P<0 \cdot 05)$. Changes in individual SCFA (data for butyrate only presented) did not, however, reach statistical significance. The differences in total SCFA were no longer evident when the incubation proceeded for $24 \mathrm{~h}$. Nevertheless, after $48 \mathrm{~h}$, unground intact effluent contained a higher concentration of the protein end-products $\mathrm{NH}_{3}(28.0$ (SE 0.5) mmol/l $v$. $23.8(\mathrm{SE} 1.7) \mathrm{mmol} / \mathrm{l}, P<0.05)$ and total phenols $(15.2$ (SE 2.4$) \mathrm{mg} / \mathrm{l} v .8 \cdot 1(\mathrm{SE} 1 \cdot 0) \mathrm{mg} / \mathrm{l}, P<0.05)$.

\section{Discussion}

This present study aimed to determine whether readily achievable modifications to a 'typical' Australian (Western-type) diet (LSD) designed to increase the intakes of starchy foods and to reduce fat intake could have beneficial effects on large bowel fermentation. Our strategy was to alter the whole diet. Legumes replaced a proportion of meat, and wholegrain muesli and bread replaced refined alternatives in a HSLFD that proved most acceptable to our subjects with an ileostomy.

Good compliance during the two diets was indicated by the recovery of total dietary fibre in the ileal effluent which was $99.7 \%$ and $100.5 \%$ of intake for the LSD and the HSLFD respectively. Interestingly, indigestible polysaccharides could be measured as dietary fibre or RS+NSP. The dietary fibre values were close to the RS+NSP value (see Table 4) for the LSD, probably because in processed foods, RS is mostly in the form of RS type 3, which is included in the dietary fibre analysis. In the HSLFD, the RS +NSP component was greater than the dietary fibre component, possibly because the dietary fibre method does not include RS type 1 and 2 in its estimation.

Ileal outputs of wet and dry digesta were 22 and $48 \%$ greater after the HSLFD. The extra dry material contained $3.9 \mathrm{~g}$ protein and $16.2 \mathrm{~g}$ total undigested polysaccharides $(\mathrm{RS}+\mathrm{NSP})$, there was a considerable enrichment of fermentable substrate potentially available to colonic flora. While oligosaccharides were measured in the effluent, the contribution of these to the total indigestible carbohydrate level even during the HSLFD was small $(0.86 \mathrm{~g} / \mathrm{d})$ when compared to the RS + NSP $(34 \cdot 3 \mathrm{~g} / \mathrm{d})$.

The complex nature of these substrates present in ileal effluent, however, complicates interpretation of the in vitro fermentations. Nevertheless, since an equal mass of dry ileal effluent was added to each incubation, the absolute concentration $(\mathrm{g} / \mathrm{g})$ of nutrients present in the substrate is likely to have had a major determining influence on fermentation. On this basis, effluent from the HSLFD was considerably enriched with starch $(0.063$ v. $0.142 \mathrm{~g} / \mathrm{g}$ for LSD and HSLFD respectively), while differences in other major substrates were minor $(0.209$ v. $0.188 \mathrm{~g} / \mathrm{g}$; fat $0.068 v$. $0.059 \mathrm{~g} / \mathrm{g}$; NSP 0.261 v. $0.271 \mathrm{~g} / \mathrm{g}$ for LSD and HSLFD respectively).

The greater absolute concentration and molar proportion of butyrate after $24 \mathrm{~h}$ fermentation with effluent from the

Table 6. Effect of grinding the ileal effluent substrate from the high-starch, low-fat diet (HSLFD) on the concentrations of fermentation end-products after $6 \mathrm{~h}$ and $48 \mathrm{~h}$ in vitro incubation $\dagger$

(Mean values with standard errors for $n 4$ per diet)

\begin{tabular}{|c|c|c|c|c|c|c|c|c|}
\hline \multirow[b]{3}{*}{ Fermentation end-product } & \multicolumn{4}{|c|}{$6 \mathrm{~h}$ in vitro incubation } & \multicolumn{4}{|c|}{$48 \mathrm{~h}$ in vitro incubation } \\
\hline & \multicolumn{2}{|c|}{ Ground } & \multicolumn{2}{|c|}{ Unground } & \multicolumn{2}{|c|}{ Ground } & \multicolumn{2}{|c|}{ Unground } \\
\hline & Mean & SE & Mean & SE & Mean & SE & Mean & SE \\
\hline Total SCFA (mmol/l) & 63.6 & $2 \cdot 1$ & $52 \cdot 8^{*}$ & $2 \cdot 8$ & 88.9 & 2.7 & $91 \cdot 2$ & 3.3 \\
\hline Butyrate $(\mathrm{mmol} / \mathrm{l})$ & 9.5 & $1 \cdot 1$ & 8.2 & 0.5 & 17.5 & 0.9 & $18 \cdot 1$ & 0.7 \\
\hline Ammonia (mmol/l) & $13 \cdot 1$ & 1.7 & $14 \cdot 0$ & 0.6 & 23.8 & 1.7 & $28 \cdot 0^{*}$ & 0.5 \\
\hline Total phenols (mg/l) & \multicolumn{2}{|c|}{ NA } & \multicolumn{2}{|c|}{ NA } & $8 \cdot 1$ & 1.0 & $15 \cdot 2^{\star *}$ & $2 \cdot 4$ \\
\hline $\mathrm{pH}$ & $6 \cdot 19$ & 0.05 & $6 \cdot 51^{*}$ & 0.06 & 6.03 & 0.15 & $6 \cdot 22$ & 0.05 \\
\hline
\end{tabular}

SCFA, short-chain fatty acid; NA, not analysed.

Mean values were significantly different from those of the ground substrates (Student's $t$ test): ${ }^{*} P<0.05,{ }^{*} P<0.01$.

†For details of diets and procedures see Tables 1 and 2 and pp. 64-66. 
HSLFD (Table 5) is consistent with observations made in vitro (Englyst et al. 1987; Goodlad \& Mathers, 1988) and in vivo (Scheppach et al 1988b; van Munster et al 1994; Phillips et al 1995; Silvester et al 1995; Mathers et al 1997) with pure substrates that fermentation of starch generates butyrate. Butyrate has importance as the preferred energy substrate for colonocytes (Roediger, 1982) and as a factor protecting normal colonic mucosal function (Sakata, 1987, 1988; Key et al. 1996; Hass et al. 1997; Mathers, 1998). In vitro, butyrate inhibits proliferation of a number of colorectal tumour cell lines (Tsao et al. 1983; Augeron \& Laboisse, 1984) suggesting that it protects against colonic carcinogenesis ( D’Argenio et al 1996).

The HSLFD also resulted in altered protein fermentation, with significantly reduced concentrations of branched-chain fatty acids, $\mathrm{NH}_{3}$ and phenol (but not $\rho$-cresol) after $24 \mathrm{~h}$ fermentation of ileal effluent (Table 5). Whilst these changes might result from the slightly reduced concentration of protein substrate, it seems more likely that they reflect a partial suppression of protein fermentation. Soluble proteins are rapidly fermented by colonic bacteria in vitro (Macfarlane \& Allison, 1986) but effluents from each diet did not differ in soluble $\mathrm{N}$ content. Instead, increased levels of fermentable polysaccharides, particularly starch, present in the HSLFD effluent may have depressed protein fermentation by providing an alternative substrate for bacterial action. Bingham (1988) has suggested a similar mechanism to explain the protective effect of starch (Cassidy et al. 1994) and NSP (Bingham et al. 1985) against development of colon cancer in epidemiological studies. $\mathrm{As} \mathrm{NH}_{3}$ and phenol are potential carcinogens (Boutwell \& Bosch, 1959; Visek, 1978), dietary modifications that reduce their concentration in the colon may be beneficial.

One limitation of conventional in vitro fermentation procedures for assessing fermentation of ileal-derived substrates is the dependence on finely ground substrates. It was apparent by visual inspection that many wholegrains and seeds and large plant fragments would have entered the colon during the HSLFD. By analogy with the effects of grinding of wholegrains on starch digestion in the small bowel (Liljeberg \& Bjorck, 1994; Livesey et al. 1995; Muir et al. 1995), we anticipated that grinding ileal effluent would alter the surface area of the substrate and increase accessibility to the bacteria, which could have important effects on the extent and pattern of fermentation. Short-term incubation $(6 \mathrm{~h})$ of the unground effluent from the HSLFD resulted in significantly lower production of SCFA and higher $\mathrm{pH}$ although these differences were no longer apparent after $48 \mathrm{~h}$ (Table 5). Grinding may therefore increase the availability of the carbohydrate substrate to the colonic bacteria, while native (unground) digesta is likely to be more slowly digested than in vitro systems might predict. This has implications for the location in the colon at which various digesta fractions are fermented, with larger particles remaining resistant until more distal sites are reached.

This present study employed minor modifications to a 'typical' Australian, Western-type diet. Many of the same foods were used although amounts were varied, some refined starchy foods were replaced with less processed alternatives, and a few additional but familiar foods such as legumes were incorporated. These changes gave a palatable and acceptable diet that potentially would result in substantially greater flows of starch or RS (4-fold) and NSP (2-fold) into the large bowel. The dietary modifications also resulted in a diet of reduced total and saturated fat content that might be expected to be advantageous in relation to the prevention of cardiovascular disease and obesity in addition to colon cancer. Although excretion of undigested polysaccharides on this diet was modest compared with that reported in previous dietary studies (Silvester et al. 1995), it was nevertheless sufficient to potentially alter colonic fermentation. In vitro incubation of ileal effluent suggests that the extra substrate provided by the HSLFD could have increased colonic SCFA production by about $50 \%$ and butyrate by about $66 \%$ whilst reducing production of protein-derived end-products. Such changes may improve colonic health and reduce the risk of colorectal cancer.

As the benefits of diets high in both RS and NSP become accepted, future research should explore other practical ways to introduce RS- and NSP-containing foods into the diet. In the present study, subjects adapted readily to a 2-fold increase in starch intake, while in a previous study (Muir et al. 1998) a 3-fold increase in starch intake was achieved. It is also noteworthy that foods rich in RS (e.g. grains and cereals) also contain protein and NSP, the combination of which will influence fermentation-dependent events. Finally, further work is also needed to determine the importance of type $1 \mathrm{RS}$, both for ileal excretion of starch and colonic fermentation.

\section{Acknowledgements}

This study was supported by scholarships to A. M. Birkitt from the Australian Postgraduate Research Council and The British Council, and a grant from Goodman Fielder Ltd. The study was conducted in the laboratories of Deakin University (Australia) and University of Newcastle upon Tyne (UK).

\section{References}

Aman P, Pettersson D, Zhang JX, Tidehag P \& Hallmans G (1995) Starch and dietary fiber components are excreted and degraded to variable extents in ileostomy subjects consuming mixed diets with wheat- or oat-bran bread. Journal of Nutrition 125, 23412347.

Asp NG (1991) Summary of general discussion on the breath test method, the ileostomy model and the intubation studies. In Methodological Aspects of in vivo Methods for Measurement of Starch Digestibility. Report of a European Flair Concerted Action Workshop, pp. 32-34 [E Gudmand-Hoyer, editor]. Copenhagen: EURESTA.

Augeron C \& Laboisse CL (1984) Emergence of permanently differentiated cell clones in a human colonic cancer cell line after treatment with sodium butyrate. Cancer Research 44, 3961-3969.

Baghurst K, Record S, Powis G \& Stafford H (1993) CSIRO Division of Human Nutrition and the Food and Nutrition Program. What are Australians Eating? Results from the 1985 and 1990 Victorian Nutrition Surveys. Adelaide: CSIRO Division of Human Nutrition.

Baghurst PA, Baghurst KI \& Record SJ (1996) Dietary fibre, nonstarch polysaccharides and resistant starch. A review. Food Australia 48, S2-S35. 
Barry J-L, Hoebler C, Macfarlane GT, Macfarlane S, Mathers JC, Reed KA, Mortensen PB, Nordgaard I, Rowland IR \& Rumney CJ (1995) Estimation of the fermentability of dietary fibre in vitro: a European interlaboratory study. British Journal of Nutrition 74, 303-322.

Bingham S (1988) Meat, starch, and nonstarch polysaccharides and large bowel cancer. American Journal of Clinical Nutrition 48, $762-767$.

Bingham SA, Williams DRR \& Cummings JH (1985) Dietary fibre consumption in Britain: new estimates and their relation to large bowel cancer mortality. British Journal of Cancer 52, 399-402.

Birkett AM, Jones GP, de Silva AM, Young GP \& Muir JG (1997) Dietary intake and faecal excretion of carbohydrate by Australians: importance of achieving stool weights greater than $150 \mathrm{~g}$ to improve faecal markers relevant to colon cancer risk. European Journal of Clinical Nutrition 51, 625-632.

Birkett AM, Jones GP \& Muir JG (1995) Simple high-performance liquid chromatographic analysis of phenol and $\rho$-cresol in urine and feces. Journal of Chromatography Biomedical Applications 674, 187-191.

Birkett AM, Muir JG, Phillips J, Jones G \& O'Dea K (1996) Resistant starch lowers fecal concentrations of ammonia and phenols in humans. American Journal of Clinical Nutrition 63, $766-772$.

Boutwell RK \& Bosch DK (1959) The tumor-promoting action of phenol and related compounds for mouse skin. Cancer Research 19, 413-427.

Candido EPM, Reeves R \& Davie JR (1978) Sodium butyrate inhibits histone deacetylation in cultured cells. Cell 14, 105113.

Cassidy A, Bingham SA \& Cummings JH (1994) Starch intake and colorectal cancer risk: an international comparison. British Journal of Cancer 69, 937-942.

Cummings JH, Beatty ER, Kingman SM, Bingham SA \& Englyst HN (1996) Digestion and physiological properties of resistant starch in the human large bowel. British Journal of Nutrition 75, 733-747.

Cummings JH, Bingham SA, Heaton KW \& Eastwood MA (1992) Fecal weight, colon cancer risk, and dietary intake of nonstarch polysaccharides (dietary fiber). Gastroenterology 103, 17831789.

Cummings JH \& Englyst HN (1995) Gastrointestinal effects of food carbohydrates. American Journal of Clinical Nutrition 61, 938S-945S

D'Argenio G, Cosenza V, Cave MD, Iovino P, Valle ND, Lombardi G \& Mazzacca G (1996) Butyrate enemas in experimental colitis and protection against large bowel cancer in a rat model. Gastroenterology 110, 1727-1734.

Edwards CA, Gibson GR, Champ M, Jensen BB, Mathers J, Nagengast F, Rumney C \& Quehl A (1996) In vitro method for quantification of the fermentation of starch by human faecal bacteria. Journal of the Science of Food and Agriculture $\mathbf{7 1}$, 209-217.

Englyst HN \& Cummings JH (1988) Improved method for measurement of dietary fiber as non-starch polysaccharides in plant foods. Journal of the Association of Official Analytical Chemists 71, 808-814.

Englyst HN, Hay S \& Macfarlane GT (1987) Polysaccharide breakdown by mixed populations of human faecal bacteria. FEMS Microbiology Letters 45, 163-171.

Englyst HN, Kingman SM, Cummings JH (1992) Classification and measurement of nutritionally important starch fractions. European Journal of Clinical Nutrition 46, S33-S50.

Folch J, Lees M \& Stanley GHS (1957) A simple method for the isolation and purification of total lipides from animal tissues. Journal of Biological Chemistry 226, 497-509.
Foster-Powell K \& Brand-Miller J (1995) International tables of glycemic index. American Journal of Clinical Nutrition 62, 871S-893S.

Goodlad JS \& Mathers JC (1988) Effects of food carbohydrates on large intestinal fermentation in vitro. Proceedings of the Nutrition Society 47, 176A.

Hass R, Busche R, Luciano L, Reale E \& van Englchardt WV (1997) Lack of butyrate is associated with induction of Bax and subsequent apoptosis in the proximal colon of guinea pig. Gastroenterology 112, 875-881.

Holland B, Unwin I \& Buss DH (1988) Cereals and Cereal Products. The 3rd supplement to McCance \& Widdowson's The Composition of Foods, 4th ed. London: H.M. Stationery Office.

Holland B, Unwin I \& Buss DH (1991) Vegetables, Herbs and Spices. The 5th supplement to McCance \& Widdowson's The Composition of Foods, 4th ed. London: H.M. Stationery Office.

Holland B, Unwin I \& Buss DH (1992) Fruit and Nuts. The 1st Supplement to McCance \& Widdowson's The Composition of Foods, 5th ed. London: H.M. Stationery Office.

Karoutis AI, Tyler RT \& Slater GP (1992) Analysis of legume oligosaccharides by high resolution gas chromatography. Journal of Chromatography 623, 186-190.

Lampe JW, Wetsch RF, Thomson WO \& Slavin JL (1993) Gastrointestinal effects of sugarbeet fiber and wheat bran in healthy men. European Journal of Clinical Nutrition 47, 543548.

Jenkins DJ, Cuff D, Wolever TM, Knowland D, Thompson L, Cohen Z \& Prokipchik E (1987) Digestibility of carbohydrate foods in an ileostomate: relationship to dietary fiber, in vitro digestibility, and glycemic response. American Journal of Gastroenterology 82, 709-717.

Key FB, McClean D \& Mathers JC (1996) Tissue hypertrophy and epithelial proliferation rate in the gut of rats fed on bread and haricot beans (Phaseolus vulgaris). British Journal of Nutrition 76, 273-286.

Liljeberg H \& Bjorck I (1994) Bioavailability of starch in bread products. Postprandial glucose and insulin responses in healthy subjects and in vitro resistant starch content. European Journal of Clinical Nutrition 48, 151-163.

Livesey G, Wilkinson JA, Roe M, Faulks R, Clark S, Brown JC, Kennedy H \& Elia M (1995) Influence of the physical form of barley grain on the digestion of its starch in the human small intestine and implications for health. American Journal of Clinical Nutrition 61, 75-81.

McBurney MI, Thompson LU, Cuff DJ \& Jenkins DJ (1988) Comparison of ileal effluents, dietary fibers, and whole foods in predicting the physiological importance of colonic fermentation. American Journal of Gastroenterology 83, 536-540.

Macfarlane GT \& Allison C (1986) Utilisation of protein by human gut bacteria. FEMS Microbiology and Ecology 38, 19-24.

Mathers JC (1998) Nutrient regulation of intestinal proliferation and apoptosis. Proceedings of the Nutrition Society 57, 219223.

Mathers JC, Smith H \& Carter S (1997) Dose-response effects of raw potato starch on small intestinal escape, large-bowel fermentation and gut transit time in the rat. British Journal of Nutrition 78, 1015-1029.

Mortensen PB (1992) The effect of oral-administered lactulose on colonic nitrogen metabolism and excretion. Hepatology 16, 1350-1356.

Muir JG, Birkett A, Brown I, Jones G \& O’Dea K (1995) Food processing and maize variety affects the amounts of starch escaping digestion in the small intestine. American Journal of Clinical Nutrition 61, 82-89.

Muir JG, Walker KZ, Kaimakamis MA, Cameron MA, Govers MJAP, Lu ZX, Young GP \& O'Dea K (1998) Modulation of 
fecal markers relevant to colon cancer risk: a high-starch Chinese diet did not generate expected beneficial changes relative to a Western-type diet. American Journal of Clinical Nutrition $\mathbf{6 8}$, 372-379.

National Food Authority (1991) Composition of Foods Australia. Canberra: Australian Government Publishing Service.

Noakes M, Clifton PM, Nestel PJ, Le Leu R \& McIntosh G (1996) Effect of high-amylose starch and oat bran on metabolic variables and bowel function in individuals with hypertriglyceridemia. American Journal of Clinical Nutrition 64, 944-951.

Phillips J, Muir JG, Birkett A, Lu ZX, Jones GP, O'Dea K \& Young G (1995) Effect of resistant starch on fecal bulk and fermentation-dependent events in humans. American Journal of Clinical Nutrition 62, 121-130.

Prosky L, Asp N-G, Furda I, DeVries JW, Schweizer TF \& Harland BF (1985) Determination of total dietary fiber in foods and food products: collaborative study. Journal of the Association of Official Analytical Chemists 68, 677-679.

Roediger WEW (1982) Utilization of nutrients by isolated epithelial cells of the rat colon. Gastroenterology 83, 424-429.

Rumney CJ \& Rowland IR (1992) In vivo and in vitro models of the human colonic flora. Critical Reviews in Food Science and Nutrition 31, 299-331.

Sakata T (1987) Stimulatory effect of short-chain fatty acids on epithelial cell proliferation in the rat intestine: a possible explanation for trophic effects of fermentable fibre, gut microbes and luminal trophic factors. British Journal of Nutrition 58, 95-103.

Sakata T (1988) Depression of intestinal epithelial cell proliferation rate by hindgut bypass in rats. Scandinavian Journal of Gastroenterology 23, 1200-1202.

Scheppach W, Fabian C, Ahrens F, Spengler M \& Kasper H (1988a) Effect of starch malabsorption on colonic function and metabolism in humans. Gastroenterology 95, 1549-1555.
Scheppach W, Fabian C, Sachs M \& Kasper H (1988b) The effect of starch malabsorption on fecal short-chain fatty acid excretion in man. Scandinavian Journal of Gastroenterology 23, 755759.

Silvester KR, Englyst HN \& Cummings JH (1995) Ileal recovery of starch from whole diets containing resistant starch measured in vitro and fermentation of ileal effluent. American Journal of Clinical Nutrition 62, 403-411.

Stephen AM, Dahl WJ, Sieber GM, van Blaricom JA \& Morgan DR (1995) Effect of green lentils on colonic function, nitrogen balance, and serum lipids in healthy human subjects. American Journal of Clinical Nutrition 62, 1261-1267.

Sundberg B, Wood P, Lia A, Andersson H, Sandberg AS, Hallmans G \& Aman P (1996) Mixed-link beta-glucan from breads of different cereals is partly degraded in the human ileostomy model. American Journal of Clinical Nutrition 64, 878-885.

Tsao D, Shi Z, Wong A \& Kim YS (1983) Effect of sodium butyrate on carcinoembryonic antigen production by human colonic adenocarcinoma cells in culture. Cancer Research 43, $1217-1222$.

van Munster IP, Tangerman A \& Nagengast FM (1994) Effect of resistant starch on colonic fermentation, bile acid metabolism, and mucosal proliferation. Digestive Diseases and Sciences 39, 834-842.

Visek WJ (1978) Diet and cell growth modulation by ammonia. American Journal of Clinical Nutrition 31, S216-S220.

Walker ARP, Walker BF \& Walker AJ (1986) Faecal pH, dietary fibre intake, and proneness to colon cancer in four South African populations. British Journal of Cancer 53, 489-495.

Walker KZ, Birkett AM, Lu ZX, Jones G, O'Dea K \& Muir JG (1997) Development of a simulated Australian diet for adults which may have use as a research tool. Australian Journal of Nutrition and Dietetics 54, 190-197. 